\title{
ArcheoSciences
}

Revue d'archéométrie

\section{Strontium isotope investigations of the Haraldskær Woman - a complex record of various tissues}

Analyse des isotopes du strontium de la Femme de Haraldskcer - un dossier complexe de tissus divers

Karin Margarita Frei, Ulla Mannering, T. Douglas Price and Rasmus Birch Iversen

\section{OpenEdition}

\section{Journals}

Electronic version

URL: https://journals.openedition.org/archeosciences/4407

DOI: $10.4000 /$ archeosciences.4407

ISBN: 978-2-7535-4778-0

ISSN: 2104-3728

\section{Publisher}

Presses universitaires de Rennes

\section{Printed version}

Date of publication: 31 December 2015

Number of pages: 93-101

ISBN: 978-2-7535-4776-6

ISSN: 1960-1360

\section{Electronic reference}

Karin Margarita Frei, Ulla Mannering, T. Douglas Price and Rasmus Birch Iversen, "Strontium isotope investigations of the Haraldskær Woman - a complex record of various tissues", ArcheoSciences [Online], 39 | 2015, Online since 31 December 2017, connection on 28 January 2022. URL: http:// journals.openedition.org/archeosciences/4407; DOl: https://doi.org/10.4000/archeosciences.4407 


\title{
Strontium Isotope Investigations of the Haraldskær Woman - A Complex Record of Various Tissues
}

\author{
Analyses des isotopes du strontium de la Femme de Haraldsker - \\ un dossier complexe de tissus divers
}

\author{
Karin Margarita Frei ${ }^{\mathrm{a}}$, Ulla Mannering ${ }^{\mathrm{b}}$, T. Douglas PrICE \\ and Rasmus BirCH IVERSEN ${ }^{\mathrm{d}}$
}

\begin{abstract}
Résumé : Bog bodies form a unique group of archaeological human remains which offer unparalleled insight into the past. Unlike most ancient human remains, bog bodies have preserved their skin and other soft tissues through natural tanning processes in the bogs. We present the first comprehensive strontium isotope investigation of the Haraldskær Woman and her garments, dated to the Scandinavian Pre-Roman Iron Age (500-1 BC). Our interdisciplinary research applies new advances in strontium isotope tracing protocols enabling us to go a step further in unravelling the life of bog people. Our study reveals long distance travel of the Haraldskær Woman shortly before her death, leading to new speculations on to why her body ended in the bog.
\end{abstract}

Abstract: Les corps humains conservés dans les tourbières forment un groupe bien particulier de restes archéologiques et offrent un aperçu unique du passé. Contrairement à la plupart des restes humains anciens, les corps déposés dans les tourbières sont parfois conservés avec des organes (peau, cheveux, etc.) grâce à des processus de tannerie naturels spécifiques au milieu tourbeux. Nous présentons la première étude isotopique complète de la femme de Haraldskar et de ses vêtements, datée de l'Âge du Fer pré-romain en Scandinavie (500-1 BC). Notre recherche interdisciplinaire applique de nouveaux protocoles de traçage isotopique du strontium et nous permet d'aller un peu plus loin dans l'évocation de la vie des gens des tourbières. Notre étude révèle un long voyage effectué par la fermme de Haraldskar peu avant sa mort, conduisant à de nouvelles hypothèses concernant la raison pour laquelle son corps se trouve dans une tourbière.

Keywords: Strontium isotopes, bog bodies, Iron Age, archaeological textiles, human hair.

Mots clés : isotopes de strontium, corps des tourbières, l'âge du fer, textiles archéologiques, des cheveux humains.

\section{INTRODUCTION}

Bog bodies are true windows to the past due to their exceptional preservation, which enable them to retain their human appearance even after being in the bog for several millennia (Glob, 965; Ilkjær, 2000; Van der Sanden, 1996). These unusual human remains have been found across north-western Europe. The majority of them have been unearthed in Scandinavia and date to the Pre-Roman Iron Age. The bog bodies represent individuals that were buried

${ }^{a}$ Environmental Archaeology and Material Science, Conservation and Natural Sciences, National Museum of Denmark, Frederiksholms Kanal 12, 1220 Copenhagen K, Denmark.

${ }^{b}$ Ancient Cultures of Denmark and the Mediterranean, Research and Collections, National Museum of Denmark, Frederiksholms Kanal 12, 1220 Copenhagen K, Denmark.

' Department of Anthropology, Laboratory for Archaeological Chemistry, University of Wisconsin, 1180 Observatory Drive, Madison, WI 53706-1393, USA.

${ }^{d}$ Moesgaard Museum, Moesgaard Alle 20, 8270 Højbjerg, Denmark. 
and/or sacrificed in the bogs in contrast to the customary traditions where the deceased were cremated and their ashes buried in urns (Becker, 1961). The excellent preservation of these bodies, combined with new developments in methods of isotopic tracing techniques, offers unique possibilities to learn hitherto unknown aspects of their life and mobility through different life stages (Bergfjord et al., 2012; Font et al., 2012; Frei et al., 2009a; Frei et al., 2015; Frei et al., 2010; Lynnerup, 2007).

Here we focus on investigating the human and textile remains of the bog body referred to as the "Haraldskær Woman" (figure 1), also known as "Queen Gunhild", with the overall aim of gaining information on her provenance.
The Haraldskær Woman was unearthed by peat-cutters in the autumn of 1835 in the Haraldskær bog near Vejle, Jutland, Denmark (figure 2). The woman was probably strangled and died at an age of c. 40 years. Inspired by the Islandic Sagas, it was suggested immediately after the recovery that this bog body belonged to the Viking queen Gunhild from Norway, who was to marry the Viking king of Denmark, Harald Bluetooth, but who instead was killed and cast into a bog. Her Viking origin was later refuted, but the name persisted through time (Worsaae, 1842). Recent ${ }^{14} \mathrm{C}$ analyses resulting in $2110 \pm 41{ }^{14} \mathrm{C}$ cal. BP (Mannring et al., 2010) have now securely placed the find in the Danish PreRoman Iron Age (500-1 BC). Like many other bog bodies,

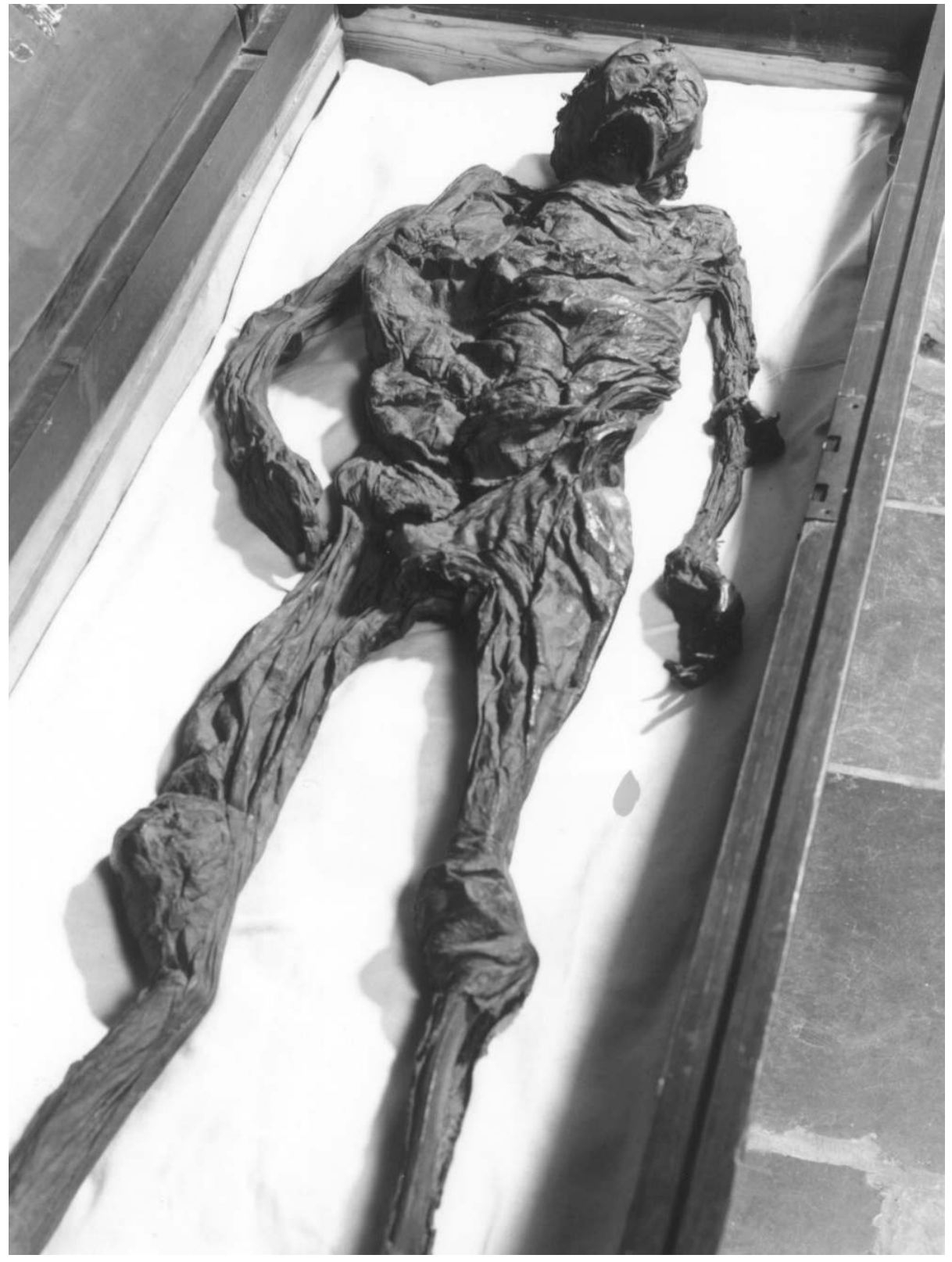

Figure 1: The bog body of the Haraldskær Woman as it is preserved today (Photo by courtesy of The Vejle Museums).

Figure 1: Le corps de la femme de Haraldskar trouvé dans la tourbière tel qu'il est conservé aujourd'hui (photo avec la permission des Musées de Vejle). 
the Haraldskær Woman was found with a rich set of wool textiles, a wool sprang cap (sprang being an ancient needlework technique), several wool cords and a skin cape (Hald, 1980) (figures 3 and 4). Moreover, her long hair $(>50 \mathrm{~cm}$, figure 4) as well as some of her teeth are also preserved, thereby providing a unique opportunity to study mobility during different life stages through recently developed strontium isotope tracing methods (Frei et al., 2015). We conducted a total of 27 strontium isotope analyses in order to investigate the provenance and mobility pattern of the Haraldskær Woman (table 1).

\section{Methods}

Recent advances in methodological strontium isotopic tracing techniques in keratin-rich animal and human tissues, provide us with new possibilities to investigate both archaeological textiles as well as ancient human hair (Frei $e t$ al., 2015; Frei et al., 2009a; Frei et al., 2010). These studies focus on developing pre-cleaning procedures that enable the recovery of the nutritional strontium fraction in hair (Font et al., 2012; Frei et al., 2015; Frei, 2014; Lynnerup, 2007). The present study applies these chemical protocols. Our sampling strategy included threads from the wool textile remains, scalp hair of the Haraldskær Woman (sampled at both ends), tooth enamel, as well as archaeological fauna, soil extracts and water samples in order to create a local reference map/isoscape.

\section{Pre-cleaning/decontamination of wool and hair samples}

Wool and human scalp hair samples were washed in $1 \mathrm{~N}$ hydrochloric $(\mathrm{HCl})$ acid and subsequently in $20 \%$ dilute cold hydrofluoric (HF) acid under ultrasonic treatment for 1 hour in a $7 \mathrm{ml}$ Teflon beaker $\left(\right.$ Savillex $\left.{ }^{\mathrm{Tm}}\right)$. The samples were rinsed twice with $1 \mathrm{ml}$ of deionized water $\left(\mathrm{MilliQ}^{\mathrm{TM}}\right)$ in an ultrasonic bath between the acid washes. The respective acid washes were subsequently pipetted off from the wool samples and the remaining wool samples were thereafter deeply rinsed (several times) with $1 \mathrm{ml}$ of deionized water $\left(\right.$ MilliQ $\left.^{\mathrm{TM}}\right)$ and dried off.

In order to remove traces of dyestuff in the textiles, the rinsed wool samples were immersed in $3 \mathrm{ml}$ of $0.2 \mathrm{M}$ ammonium peroxodisulfate $\left(\mathrm{NH}_{4}\right)_{2} \mathrm{~S}_{2} \mathrm{O}_{8}$ (a strong oxidant, abbreviated as "APDS") on a hotplate (preferably at $130^{\circ} \mathrm{C}$ ) for c. 30 minutes. The residual wool sample was once again deeply rinsed with $1 \mathrm{ml}$ of deionized water $\left(\mathrm{Milli}^{\mathrm{TM}}\right)$ several times and subsequently dried off.
The final residual wool/hair portions were dissolved in a 1:1 mixture of $30 \% \mathrm{HNO}_{3}\left(\right.$ Seastar $\left.^{\mathrm{TM}}\right)$ and $30 \% \mathrm{H}_{2} \mathrm{O}_{2}$ $\left(\right.$ Seastar $\left.^{\mathrm{TM}}\right)$. The samples tended to decompose within 30 minutes. After decomposition the solutions were dried off on a hotplate at c. $80^{\circ} \mathrm{C}$.

Samples were taken up in a few drops of $3 \mathrm{~N}^{-\mathrm{HNO}_{3}}$ and loaded on especially prepared, disposable pipette-tip columns containing $0.2 \mathrm{ml}$ intensively pre-cleaned mesh 50-100 SrSpec ${ }^{\text {TM }}$ (Eichrome Inc./Tristchem) ion chromatographic resin. The elution recipe essentially followed that of (Horwitz et al., 1992).

Strontium from enamel-, bone-, soil extract- and water samples was separated according to the analytical procedures and protocols described by Frei and Frei (2010), and Montgomery (2010) and $\mathrm{Sr}$ fractions from these samples, analogues for wool textile and hair samples were measured on the same facility described below.

\section{Thermal ionization mass spectrometry}

The samples were dissolved in $2.5 \mu \mathrm{l}$ of a $\mathrm{Ta} 2 \mathrm{O} 5$ H3PO4-HF activator and subsequently loaded onto outgassed $99.98 \%$ single rhenium filaments. Samples were measured in a dynamic mode on a VG 54 Sector IT mass spectrometer (at the Danish Center for Isotope Geology, University of Copenhagen), at temperatures between 1300 and $1450^{\circ} \mathrm{C}$. The mass 88 ion beam was kept above $300 \mathrm{mV}$ during an analytical run which consisted of over a minimum of 6 blocks with 10 mass scan cycles each.

\section{RESULTS AND MATERIALS}

New achievements in the field of ancient wool textile and human hair analyses (Font et al., 2012, Frei et al., 2015; Frei 2014, Frei et al., 2009a, Frei et al., 2010; Lynnerup, 2007), have for the first time made it possible to conduct a complete provenance investigation of a bog body (including teeth, scalp hair and garments) using the strontium isotope tracing system. The exceptional preservation of the Haraldskær find provides a unique opportunity to build a sequence of time-snapshots indicating where the woman lived and where her garments were produced (Table 1).

\section{Local baseline}

The isotopic range of bioavailable strontium for Denmark has recently been defined by surface waters and soil extracts (Frei and Frei, 2011; Frei and Frei 2013) and by modern and archaeological fauna samples (Frei and Price, 2012). 


\begin{tabular}{|c|c|c|c|c|c|c|}
\hline Sample identification & Material & $\begin{array}{c}\text { Weight } \\
(m g)\end{array}$ & Procedure & $\begin{array}{c}\text { [Sr] } \\
(p p m)\end{array}$ & ${ }^{87} \mathrm{Sr} /^{86} \mathrm{Sr}$ & $\begin{array}{c}2 \sigma \\
(a b s)\end{array}$ \\
\hline \multicolumn{7}{|l|}{ Textiles } \\
\hline NM 3706 weft & textile/wool & 11,81 & $\mathrm{HF}+\mathrm{HCl}$ leach & 29 & 0,70995 & 0,00004 \\
\hline NM 3706 weft & textile/wool & 11,81 & APDS leach & 32,8 & 0,70929 & 0,00003 \\
\hline NM 3706 weft & textile/wool & 11,81 & residue & 0,54 & 0,70946 & 0,00002 \\
\hline NM 3706 warp & textile/wool & 12,43 & $\mathrm{HF}+\mathrm{HCl}$ leach & 27,95 & 0,70995 & 0,00004 \\
\hline NM 3706 warp & textile/wool & 12,43 & APDS leach & 31,84 & 0,70929 & 0,00003 \\
\hline NM 3706 warp & textile/wool & 12,43 & residue & 0,26 & 0,70993 & 0,00003 \\
\hline NM 3707 C2 & textile/wool & 3,48 & HF leach & 4,48 & 0,71910 & 0,00006 \\
\hline NM 3707 C2 & textile/wool & 3,48 & $\mathrm{HCl}$ leach & 1,05 & 0,71712 & 0,00007 \\
\hline NM 3707 C2 & textile/wool & 3,48 & APDS leach & 3,3 & 0,71137 & 0,00004 \\
\hline NM 3707 C2 & textile/wool & 3,48 & residue & 1,15 & 0,71283 & 0,00006 \\
\hline NM 3707 C1* & textile wool & 17,53 & residue & 3,14 & 0,70924 & 0,00002 \\
\hline NM C 37143 net & wool hair net/sprang & 27,13 & $\mathrm{HF}+\mathrm{HCl}$ leach & 15,96 & 0,70921 & 0,00003 \\
\hline NM C 37143 net & wool hair net/sprang & 27,13 & residue & 4,68 & 0,70839 & 0,00009 \\
\hline NM C 37143 cord & wool hair net/outer cord & 11,78 & $\mathrm{HF}+\mathrm{HCl}$ leach & 29,29 & 0,70995 & 0,00004 \\
\hline NM C 37143 cord & wool hair net/outer cord & 11,78 & APDS leach & 33,81 & 0,70921 & 0,00003 \\
\hline NM C 37143 cord & wool hair net/outer cord & 11,78 & residue & 0,53 & 0,70921 & 0,00003 \\
\hline \multicolumn{7}{|l|}{ Human remains } \\
\hline NM 3708 (segment 1) & Human hair & 7,21 & $\mathrm{HF}+\mathrm{HCl}$ leach & 121,09 & 0,70992 & 0,00003 \\
\hline NM 3708 (segment 1) & Human hair & 7,21 & residue & 10,72 & 0,70687 & 0,00006 \\
\hline NM 3708 (segment 2) & Human hair & 15,51 & $\mathrm{HF}+\mathrm{HCl}$ leach & 17,73 & 0,70967 & 0,00004 \\
\hline NM 3708 (segment 2) & Human hair & 15,51 & residue & 7,29 & 0,70856 & 0,00006 \\
\hline E 1 & Enamel from front tooth & 1,35 & $\mathrm{HCl}-\mathrm{H}_{2} \mathrm{O}_{2}$ & & 0,70847 & 0,00003 \\
\hline \multicolumn{7}{|l|}{ Baseline samples } \\
\hline $\mathrm{H} 3$ & Tooth enamel from archaeological rodent & 6,64 & $\mathrm{HCl}-\mathrm{H}_{2} \mathrm{O}_{2}$ & & 0,70935 & 0,00002 \\
\hline $\mathrm{H} 4$ & Tooth enamel from archaeological rodent & 5,13 & $\mathrm{HCl}-\mathrm{H}_{2} \mathrm{O}_{2}$ & & 0,70936 & 0,00001 \\
\hline H5 & Tooth enamel from archaeological rodent & 8,95 & $\mathrm{HCl}-\mathrm{H}_{2} \mathrm{O}_{2}$ & & 0,70936 & 0,00001 \\
\hline H6 & Jaw bone fragment from archaeological rodent & 8,76 & $\mathrm{HCl}-\mathrm{H}_{2} \mathrm{O}_{2}$ & & 0,70975 & 0,00002 \\
\hline $\mathrm{H} 7$ & Jaw bone fragment from archaeological rodent & 19,77 & $\mathrm{HCl}-\mathrm{H}_{2} \mathrm{O}_{2}$ & & 0,70944 & 0,00001 \\
\hline W1 & Surface water, Haraldskær creek & $10 \mathrm{ml}$ & & & 0,70894 & 0,00001 \\
\hline S1 & Soil, Haraldskær peat bog & $1 \mathrm{~g}$ & $0.05 \mathrm{~N} \mathrm{HNO}_{3}$ extract & & 0,70943 & 0,00001 \\
\hline \multicolumn{5}{|c|}{ Median of fauna, water and soil samples } & \multicolumn{2}{|l|}{0,70936} \\
\hline \multicolumn{5}{|l|}{ Baseline range } & \multicolumn{2}{|l|}{$0.70894-0.70975$} \\
\hline
\end{tabular}

* Sample previously analyzed by Frei et al. (2009a)

Table 1: Strontium isotopic compositions of the Haraldskær woman and her textiles as well as baseline materials

Tableau 1: Compositions isotopiques du strontium de la femme de Haraldskar et ses textiles ainsi que des matériaux de référence.

This baseline characterization resulted in a range of ${ }^{87} \mathrm{Sr} /{ }^{86} \mathrm{Sr}$ values between $-0.708-0.711$ (island of Bornholm excluded). In addition to this, we measured ${ }^{87} \mathrm{Sr} /{ }^{86} \mathrm{Sr}$ ratios in a variety of materials from the Haraldskær site where the body was discovered and hence further narrowed down the isotopic range of local bioavailable strontium (Table I) to ${ }^{87} \mathrm{Sr} /{ }^{86} \mathrm{Sr}=0.7089-0.7097$.

\section{Teeth and hair}

Most bog bodies (not to be confused with bog skeletons), unlike most other ancient human remains, have preserved parts of their soft tissues, such as skin, and in some cases, even internal organs. This is due to the bio- and geochemical conditions in ombrotrophic bogs developing an acidic, anoxic 
Figure 2: (See colour plate IV) Map indicating the location of the Haraldskær bog (red star). The red spots mark areas characterized by isotope ratios of bioavailable strontium with values of ${ }^{87} \mathrm{Sr} /{ }^{86} \mathrm{Sr}<0.707$ which could match the strontium isotopic composition measured in one of the scalp hair segments of the Haraldskær Woman (segment 1) (Map by Christian Schmidt). Figure 2: (Voir planche couleur IV) Carte indiquant l'emplacement de la tourbière de Haraldsker (étoile rouge). Les taches rouges marquent les zones caractérisées par des rapports de strontium biodisponible isotopiques avec des valeurs $\mathrm{de}^{87} \mathrm{Sr}{ }^{\beta 6} \mathrm{Sr}$ $<0,707$ qui pourrait correspondre à la composition isotopique de strontium mesurée dans l'un des segments de cheveux du cuir chevelu de la femme de Haraldskar (segment 1) (Carte de Christian Schmidt).

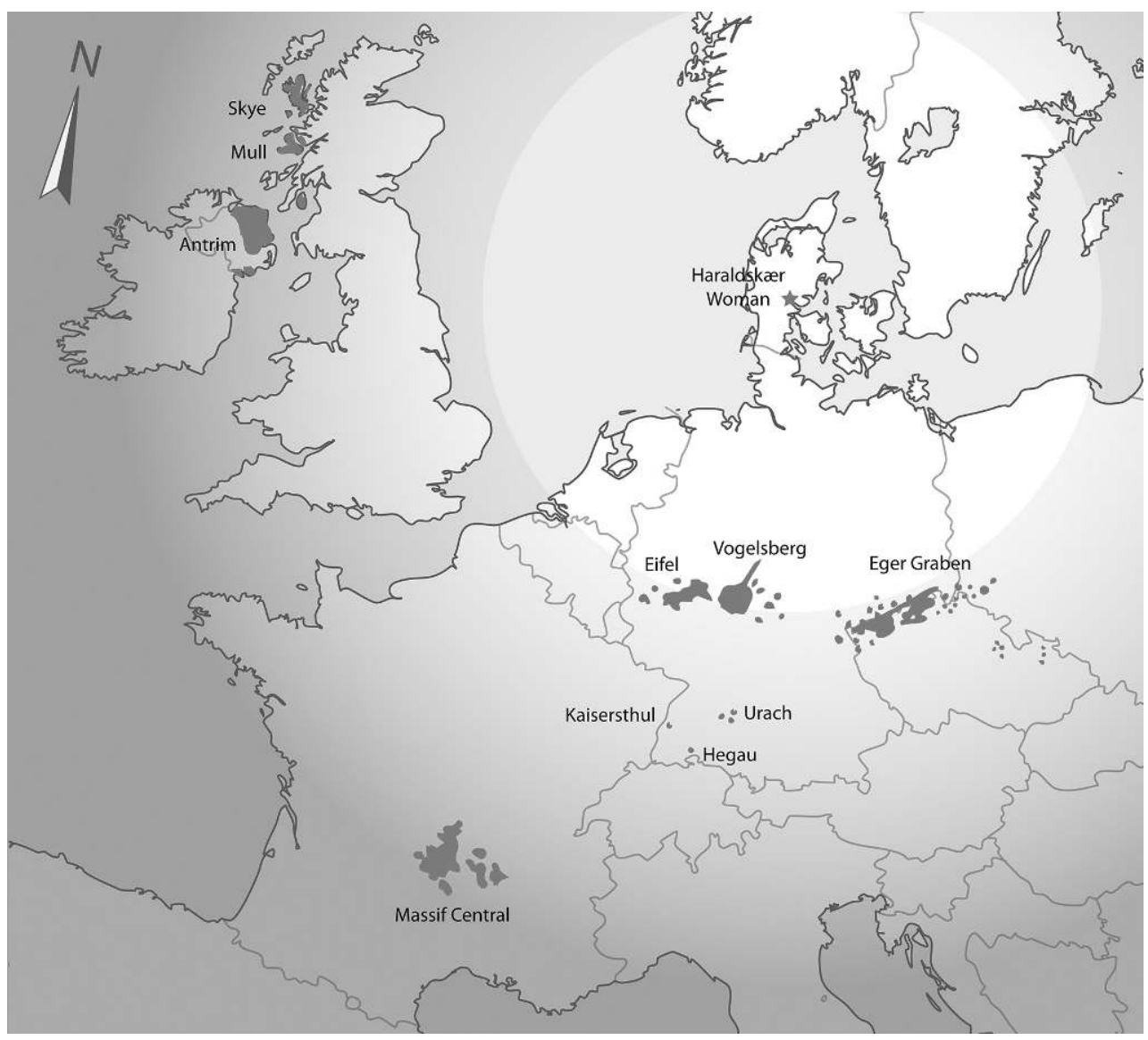

Figure 3: (See colour plate V) Textile remains from the Haraldskær Woman; a) NM 3706 which measures $64 \times 49 \mathrm{~cm}$ and was sampled in both thread directions, b) NM 3707 C1 which measures $30 \times 24 \mathrm{~cm}$ and has fringes in one end and narrow stripes in both thread directions, and c) NM 3707 C2 measures $76 \times 26 \mathrm{~cm}$ and has a chequered pattern. Black bars indicate $10 \mathrm{~cm}$ scale. The chequered textile is made of wool characterized by a strontium isotopic ratio that is too radiogenic to be of local provenance (Photos by the National Museum of Denmark).

Figure 3 : (Voir planche couleur V) Restes de textile de la femme de Haraldskar; a) NM 3706 qui mesure $64 \times 49 \mathrm{~cm}$ et a été échantillonné dans les deux directions du fil, b) NM 3707 C1 qui mesure $30 \times 24 \mathrm{~cm}$ et a des franges dans une extrémité et des bandes étroites à rayures dans les deux directions de fil, et c) NM 3707 mesures C2 $76 \times 26 \mathrm{~cm}$ et dispose d'un motif en damier. Des barres noires indiquent $10 \mathrm{~cm}$ en échelle. Le textile en damier est fait de laine caractérisée par un rapport isotopique du strontium qui est trop radiogenique pour être de provenance locale (Photos du Musée national du Danemark).
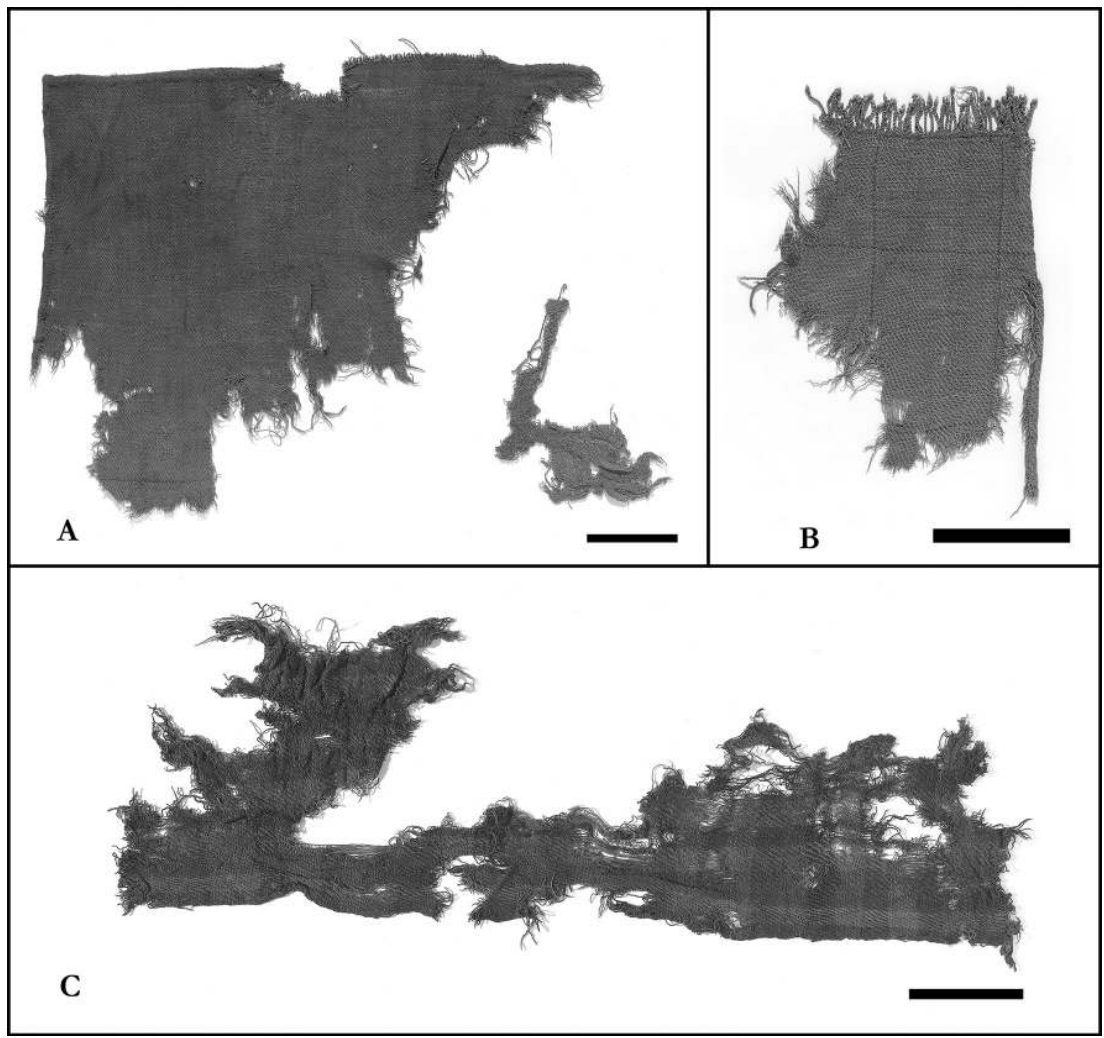
and nitrogen-rich environment (Verhoeven et al., 1990) which enables protein-based tissues to be preserved. Hair is a unique archive of, e.g. diet which can be traced by stable isotopes (Wilson et al., 2012), or of movement, potentially traceable by strontium isotopes (Frei et al., 2015). The scalp hair of the Haraldskær Woman measures over $50 \mathrm{~cm}$ in length and represents approximately 50 months of hair growth prior to death. We analyzed both ends of the scalp hair: segment 1 (near the scalp) represents the final 4-5 months of her life and yields ${ }^{87} \mathrm{Sr} /{ }^{86} \mathrm{Sr}=0.70687$; segment 2 represents a period approximately four years prior her death for 3 to 4 months time, and yields ${ }^{87} \mathrm{Sr} /{ }^{86} \mathrm{Sr}=0.70856$. Finally, the tooth enamel sample from one of her incisors yields a ${ }^{87} \mathrm{Sr} /{ }^{86} \mathrm{Sr}$ ratio of 0.70847 (table 1).

\section{Textiles}

The Haraldskær Woman was recovered together with three wool textiles, two wool accessories and a skin cape (figures 3 and 4 ). The textiles were severely damaged during the recovery and the largest textile (NM 3706) now measures $64 \times 49 \mathrm{~cm}$. It is woven in $2 / 2$ twill with $\mathrm{z}$-twisted yarn in both directions (Hald, 1980). The weft sample yields a ${ }^{87} \mathrm{Sr} /{ }^{86} \mathrm{Sr}$ ratio of 0.70946 and the warp yields a ${ }^{87} \mathrm{Sr} /{ }^{86} \mathrm{Sr}$ ratio 0.70993 . The second textile (NM $3707 \mathrm{C} 2$ ), measuring $76 \times 26 \mathrm{~cm}$ and woven in $2 / 2$ twill in s-twisted yarn, has a large chequered pattern. This textile has recently been shown to contain trace amounts of organic dyestuffs (luteolin and quercetin) (Vanden Berghe et al., 2009). Hence, all the textiles were analyzed following a new methodology developed for ancient textiles dyed with organic dyes (Frei et al., 2010). The thread sample from this textile yields a ${ }^{87} \mathrm{Sr} /{ }^{86} \mathrm{Sr}$ ratio of 0.71283 . The third textile (NM $3707 \mathrm{C} 1$ ) has a fringe and is woven in $2 / 2$ twill in z-twisted yarn in both directions. It measures $30 \times 24 \mathrm{~cm}$. A thread sample from this textile was analyzed in an earlier investigation, and yielded a ${ }^{87} \mathrm{Sr} /{ }^{86} \mathrm{Sr}$ ratio of 0.70924 (Frei et al., 2009a). The accessories consist of a wool sprang cap (NM C 37143) and several wool cords. Finally, we analyzed two samples from the cap, which yield $\mathrm{a}^{87} \mathrm{Sr} /{ }^{86} \mathrm{Sr}$ ratio of 0.70839 and $\mathrm{a}^{87} \mathrm{Sr} /{ }^{86} \mathrm{Sr}$ ratio of 0.70982 .

\section{DisCUSSION AND CONCLUSION}

The remarkable preservation of bog bodies provides an immense research potential for multidisciplinary investigations, however, key questions related to their identity and provenance still remain unanswered. In this study we have investigated the provenance of the bog body of the Haraldskær Woman dated to $2110 \pm 41{ }^{14} \mathrm{C}$ cal. BP (Mannering et al., 2010).

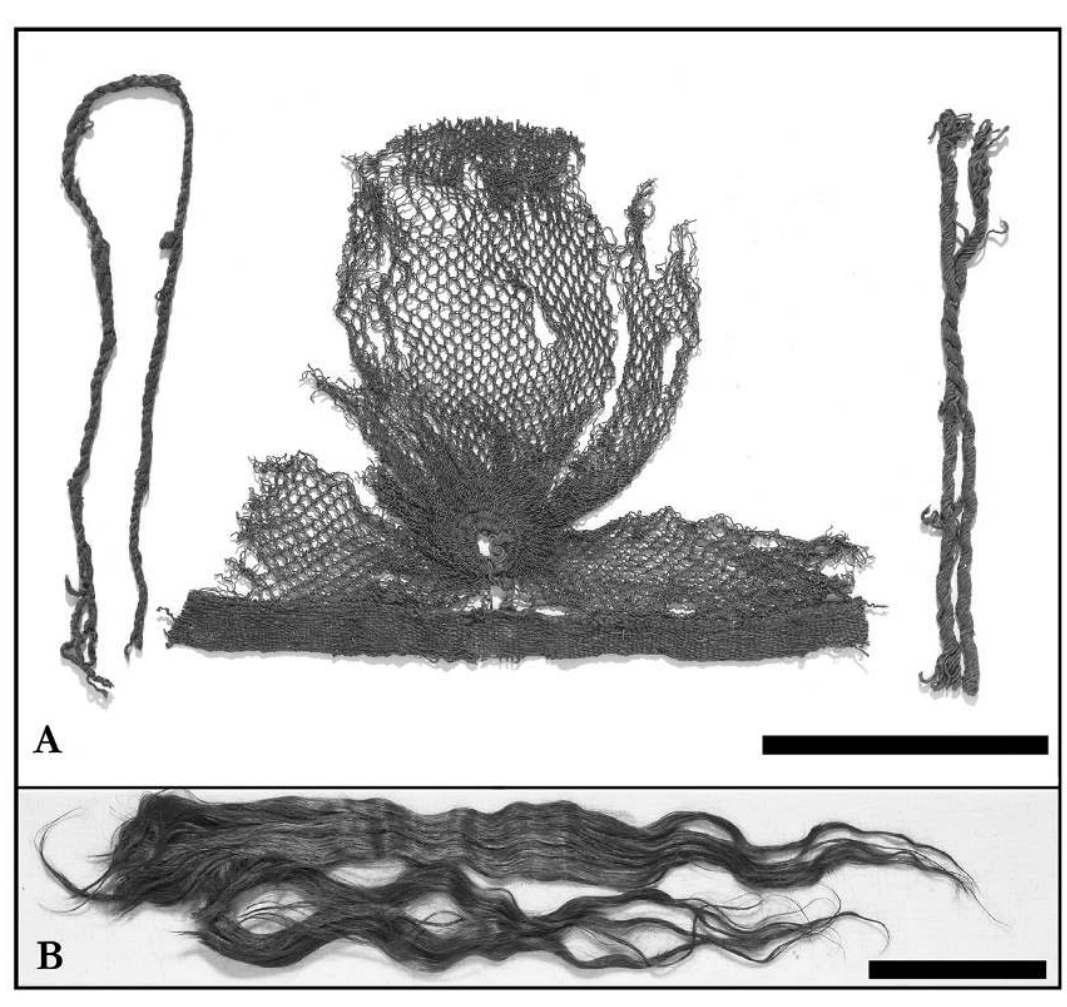

Figure 4: (See colour plate) a) Sample NM C 37143, a wool sprang cap or hairnet which was sampled at the edge (cord) and in the middle part. b) Detached scalp hair from the Haraldskær Woman measuring over $50 \mathrm{~cm}$ in length. The hair was sampled at both ends. Black bars indicate $10 \mathrm{~cm}$ scale. The wool accessory samples all have strontium isotope ratios that fall within the Danish bio-available isoscape. However, one of the Haraldskær Woman's scalp hair segments is of non-local provenance, indicating mobility outside Denmark (Photos by the National Museum of Denmark).

Figure 4: (Voir planche couleur) a) échantillon NMC 37143, un fichu de laine fait de la méthode "sprang" ou un bonnet qui a été échantillonné au bord (cordon) et dans la partie médiane. b) Une partie de la chevelure de la fermme de Haraldskar mesure du cuir chevelu plus de $50 \mathrm{~cm}$ de longueur. Les cheveux ont été échantillonnés aux deux extrémités. Des barres noires indiquent 10 cm d'échelle. Les échantillons d'accessoires de laine ont tous les rations des isotopes du strontium qui relèvent $d u$ isoscape biodisponible danois. Cependant, l'un des segments de cuir chevelu des cheveux de la femme de Haraldsker n'est pas de provenance locale, indiquant la mobilité en dehors du Danemark (Photos par le musée National du Danemark). 
The strontium isotope analyses of the Haraldskær Woman's tooth representing the period of childhood, fall within the isotopic range of Danish bioavailable strontium, indicating that the Haraldskær Woman probably spent her childhood in the present Danish area (excluding Bornholm). The strontium isotope composition of hair segment 2 (representing a period of approximately four years prior to her death) is similar to that of the tooth enamel. This can be interpreted in several ways. The woman either lived in a place with a similar bioavailable strontium signature or she spent most of her life in the Haraldskær area. However, hair segment 1 near the scalp (representing a few months prior to her death) has a strontium isotopic composition that lies significantly below $\left({ }^{87} \mathrm{Sr} /{ }^{86} \mathrm{Sr}\right.$ ratio of 0.70687$)$ the range of bioavailable strontium typical of present day Denmark. Such low strontium isotope values are not found in areas adjacent to Denmark and therefore this value could indicate long distance movement shortly before her death. Figure 2 shows areas with such low bioavailable strontium isotope values (Frei and Frei, 2011; Heidal et al., 2007; Löfvendahl et al., 1990; Maurer et al., 2012; Montgomery et al., 2006; Voerkelius et al., 2010; Aarberg and Wickman, 1987).

Furthermore, the analyses of two of the three textiles as well as the accessories have primarily yielded strontium isotope values which are indicative of a raw material of local provenance. However, the chequered textile is characterized by a strontium isotope value implying a non-local provenance. Altogether, the strontium isotopic evidence presented via the human remains and the textiles shows an unexpected complexity in the mobility of the Haraldskær Woman, and challenges previous held assumptions on why these people ended in the bogs as well as hypotheses about their status in Early Iron Age society. For example, the high quality of the textiles of the Haraldskær Woman indicates that she was of high status, and the strontium isotope analyses reveal that she had access to wool or textiles produced outside the present Danish area (excluding Bornholm). Additionally, she had been on a long journey probably to more southern parts of Europe, shortly before her return to Denmark where she died soon after.

The Danish Pre-Roman Iron Age has often been characterized by scholars as a period where Scandinavia became marginal in relation to other European areas, as the development that Central and especially Southern Europe went through bypassed it (Jensen, 2003). In contrast to the preceding Bronze Age society, the Early Iron Age society was characterized by a much lower import of high value goods, representing a less stratified society and possibly a higher sense of communal feeling. However, there is still some evidence of contact between southern Scandinavia and Central
Europe in the centuries before the Common Era, and an indirect influence from the Celtic areas may still be observed in the practice of sacrificing weapons in lakes and bogs as known from the Danish Hjortspring and Krogbølle finds, dated between 350-250 BC. Furthermore, it is likely that some of the old exchange and trading networks were maintained, and the Haraldskær Woman and her textiles definitely support this assumption (Bergfjord et al., 2012; Frei et al., 2015). The unusual manner and environment in which bog bodies from this period were buried/placed instead of being cremated and buried in local communal cemeteries indicate that the bog people had a special social position. The trauma observed, sometimes leading to death, that some of the bog bodies were exposed to, has often been interpreted as a kind of social punishment (Van er Sanden, 1996). Yet, a recent study of the bog bodies indicates that violence, and especially post-mortem violence, could have been an integral part of sacrificial rituals, similar to those observed on sacrificed weapons (Möller-Wiering, 2011; Ravn, 2010). Moreover, it is important to be aware that some earlier observed evidence of violence and traumas could have occurred subsequent to death, e.g. by the turf diggers when the bodies were discovered (Lynnerup, 2007). Nevertheless, their unusual location in the bog makes a sacrificial nature most likely, especially when the large number of other artefacts unearthed from the Danish bogs is taken into consideration (Jansen, 2003). Yet, it cannot be excluded that other bog bodies should be interpreted as burials, and the relative large number of the Danish bog bodies (34\%) wearing or wrapped in textiles and different skin materials that could be interpreted as grave goods definitely support this interpretation (Hald, 1980; Ravn, 2010).

The new information about the Haraldskær Woman that can be extracted on the basis of the strontium isotope analyses of human remains and textiles thus amplify our knowledge of the bog bodies, their social status and way of living. Furthermore, the analysis supports the results from earlier strontium isotope analyses of other Pre-Roman Iron Age textiles, like those found in the Huldremose bog in Denmark, revealing that, in this period, wool of both local and non-local provenance was used in textile production (Frei, 2009b). At present it is difficult to assess where exactly the Haraldskær Woman stayed shortly before her death, as this requires the establishment of broader and more detailed European strontium isotope isoscapes. In the future, continued investigations will hopefully provide better and more detailed databases that permit us to re-assess this question. Until then, the interdisciplinary study of the Haraldskær Woman and her textiles can be used to demonstrate the complexity and mobility in prehistoric human life and sheds 
new light on the choices and rituals that led to the depositions of human remains in the North European bogs.

\section{Acknowledgements}

We wish to thank Irene Skals and Lise Ræder Knudsen for help with sampling and Cristina Olsen for work in the clean labs. A special thanks to Robert Frei for providing access to the Danish Center for Isotope Geology at the University of Copenhagen as well as for his and Toby Leeper's help with mass spectrometrical analyses. We are grateful to Poul Otto Nielsen and Per Kristian Madsen for providing access to the National Museum of Denmark collections and to Roberto Fortuna for the textile pictures and Sidsel Frisch for editing the pictures. We also thank Mads Ravn and The Vejle Museums for providing the Haraldskær Woman picture. We also wish to thank Christian Schmidt for making the map and Cherine Munkholt and Michelle Garnier for improving the English and French text respectively. Finally, we thank the Danish National Research Foundation's Centre for Textile Research (DNRF 64) and Carlsberg Foundation ref. nr. 2013-01-0280 to KMF, for financial support.

\section{Bibliography}

Becker C. J., 1961. Førromersk Jernalder, I syd og midtjylland. København, Nationalmuseet.

Bergfjord C., Mannering U., Frei K. M., Gleba M., Scharff A. B., Skals I., Heinemeier J., Nosch M. L., Holst B., 2012. Nettle as a distinct Bronze Age textile plant. Sci. Rep., v. 2.

Font L., van der Peijl G., van Wetten I., Vroon P., van der Wagt B., Davies G., 2012. Strontium and lead isotope ratios in human hair: investigating a potential tool for determining recent human geographical movements. Journal of Analytical Atomic Spectrometry, v. 27, 5: 719-732.

Frei K. M., 2014. Provenance of archaeological wool textiles: new case studies. Open Journal of Archaeometry, v. 2, 1.

Frei K. M., Frei R., 2011. The geographic distribution of strontium isotopes in Danish surface waters - A base for provenance studies in archaeology, hydrology and agriculture. Applied Geochemistry, v. 26: 326-340.

Frei K. M., Frei R., Mannering U., Gleba M., Nosch M. L., Lyngstrøm H., 2009a. Provenance of ancient textiles - a pilot study evaluating the strontium isotope system in wool. Archaeometry, v. 51, 2: 252-276.

Frei K. M., Mannering U., Kristiansen K., Allentoft M. E., A.S., W., Skals I., Tridico S., Nosch M. L., Willerslev E., Clarke L., Frei R., 2015. Tracing the dynamic life story of a
Bronze Age Female. Scientific Reports, 5, 10431; doi: 10.1038/ srep 10431.

Frei K. M., Price T. D., 2012. Strontium isotopes and human mobility in prehistoric Denmark. Archaeological and Anthropological Sciences, 4 : 103-114.

Frei K. M., Skals I., Gleba M., and Lyngstrøm H., 2009 b. The Huldremose Iron Age textiles, Denmark: an attempt to define their provenance applying the Strontium isotope system. Journal of Archaeological Science, v. 36: 1965-1971.

Frei K. M., Vanden Berghe I., Frei R., Mannering U., LyNGSTRøM H., 2010. Removal of organic dyes from woolimplications for ancient textiles provenance studies. Journal of Archaeological Science, v. 37: 2136-2145.

Frei R., Frei K. M., 2013. The geographic distribution of Sr isotopes from surface waters and soil extracts over the island of Bornholm (Denmark) - A base for provenance studies in archaeology and agriculture. Applied Geochemistry, v. 38: 147-160.

GLoв P. V., 1965. Mosefolket. Jernalderens Mennesker bevaret i 2000 aar., Copenhagen, Gyldendal.

Hald M., 1980. Ancient Danish Textiles from bogs and burials. Publications of the National Museum of Denmark.

Heidel C., Tichomirowa M., Matschullat J., 2007. Lead and strontium isotopes as indicators for mixing processes of waters in the former mine "Himmelfahrt Fundgrube", Freiberg (Germany). Isotopes in Environmental and Health Studies, v. 43, no. 4: 339-354.

Horwitz E. P., Chiarizia R., Dietz R. W., 1992. A novel strontium-selective extraction chromatographic resin: Solvent Extraction and Ion Exchange. v. 10: 313-336.

ILKJÆR J., 2000. Illerup Ådal-et arkæologisktryllespejl, Moesgård.

Jensen J., 2003. Danmarks Oldtid, Eldre Jernalder 500 f.Kr. 400 e.Kr., København, Gylndendalske Boghandel.

Lynnerup N., 2007. Mummies. American Journal of Physical Anthropology, v. 134, no. S45: 162-190.

Löfvendahl R., Åberg G., Hamilton J., 1990. Strontium in rivers of the Baltic Basin. Aquatic Sciences, v. 52, no. 4: 315329.

Mannering U., Possnert G., Heinemeier J., Gleba M., 2010. Dating Danish textiles and skins from bog finds by means of C-14 AMS. Journal of Archaeological Science, v. 37, no. 2: 261-268.

Maurer A. F., Galer S. J. G., Knipper C., Beierlein L., Nunn E. V., Peters D., Tutken T., Alt K. W., Schone B. R., 2012. Bioavailable $\mathrm{Sr}-87 / \mathrm{Sr}-86$ in different environmental samples - Effects of anthropogenic contamination and implications for isoscapes in past migration studies: Science of the Total Environment, v. 433: 216-229.

Möller-Wiering S., 2011. War and Worship: Textiles from 3rd to 4th-century AD Weapon Deposits in Denmark and Northern Germany. Oxford, Oxbow Books, Ancient Textiles Series. 
Montgomery J., 2010. Passports from the past: Investigating human dispersals using strontium isotope analysis of tooth enamel. Annals of Human Biology, v. 37, no. (3) May-June: 325-346.

Montgomery J., Evans J. A., Wildman G., 2006. Sr-87/Sr-86 isotope composition of bottled British mineral waters for environmental and forensic purposes. Applied Geochemistry, v. 21, no. 10: 1626-1634.

Ravn M., 2010. Burials in Bogs, Bronze and Early Iron Age bog bodies from Denmark. Acta Archaeologica, v. 81: 112-123.

VAn Der SAnden W. A. B., 1996. Through Nature to Eternity-The Bog Bodies of Northwest Europe. Amsterdam, Batavian Lion International.

Vanden Berghe I., Gleba G., Mannering U., 2009. Towards the identification of dyestuffs in Early Age Scandinavian peat bog textiles. Journal of Archaeological Science, v. 36: 1910-1921.

Verhoeven J. T. A., Maltby E., Schmitz M. B., 1990. Nitrogen and Phosphorus Mineralization in Fens and Bogs. Journal of Ecology, v. 78, no. 3: 713-726.

Voerkelius S., Gesine D. L., Rummel S., Quétel C. R., Heiss G., Baxter M., Brach-Papa C., Deters-Itzelsberger P.,
Hoelzl S., Hoogewerff J., Ponzevera E., Van Bocxstaele M., Ueckermann H., 2010. Strontium isotopic signatures of natural mineral waters, the reference to a simple geological map and its potential for authentication of food. Food Chemistry, v. 118, no. 4: 933-940.

Wilson A. S., Taylor T., Ceruti M. C., Chavez J. A., Reinhard J., Grimes V., Meier-Augenstein W., Cartmell L., Stern B., Richards M. P., Worobey M., Barnes I., Gilbert M. T. P., 2007. Stable isotope and DNA evidence for ritual sequences in Inca child sacrifice. Proceedings of the National Academy of Sciences, v. 104, no. 42: 16456-16461.

Worsaae J. J. A., 1842. Hvorvidt man kan antage, at det i Haraldskærmosen (1835) opgravede Liig er den norske Dronning Gunhildes. In C. Molbech (ed.), Historisk Tidskrift, Volume 3, Den Danske Historiske Forening, p. 249-293.

Aaberg G., Wickman F. E., 1987. Variations of 87 Sr/86Sr in water and streams discharging into the Bothnian Bay, Baltic Sea. Nordic Hydrology, v. 18, no. 1: 33-42. 
a)

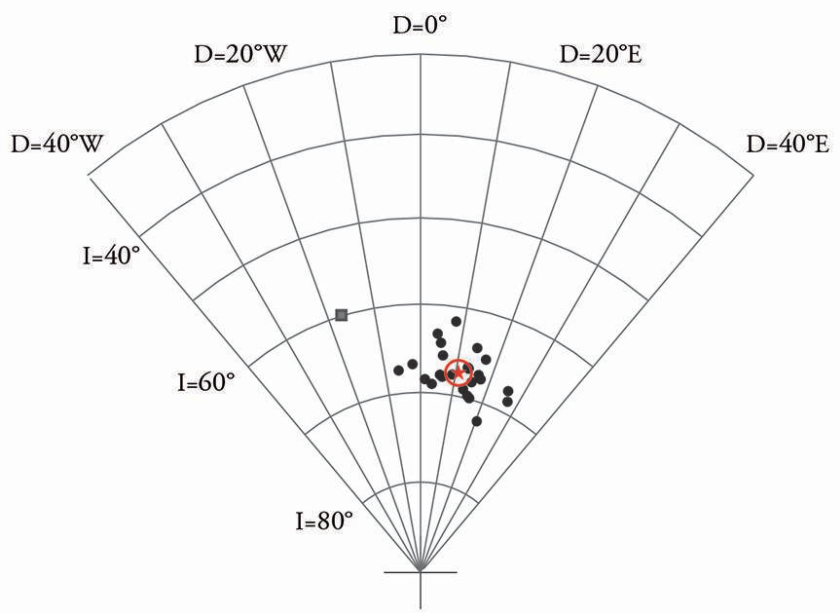

b)

Foyer AM02

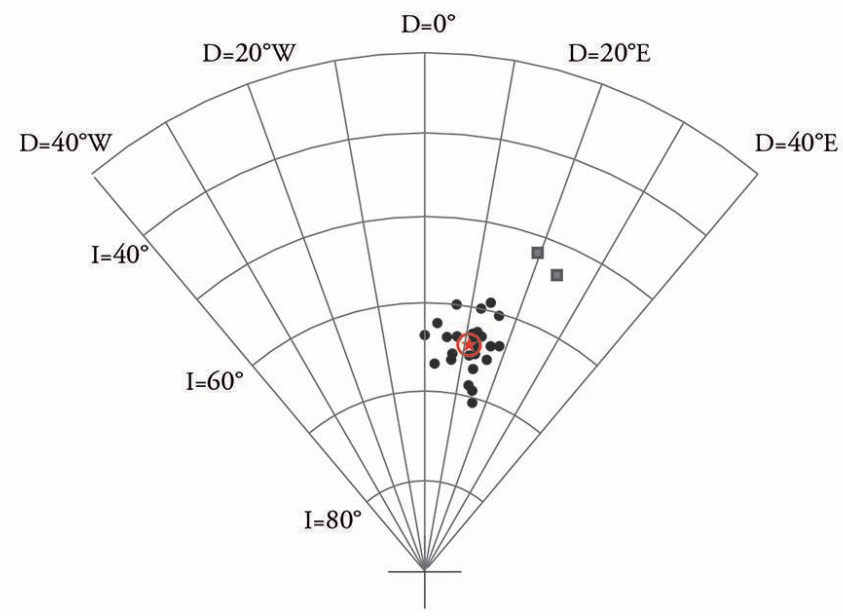

Figure 3 : Benoît RouzeAu et al., L'activité métallurgique à l'abbaye de Morimond (Haute-Marne) : nouvel éclairage de la fouille à partir de l'analyse archéomagnétique de deux foyers (p. 40)

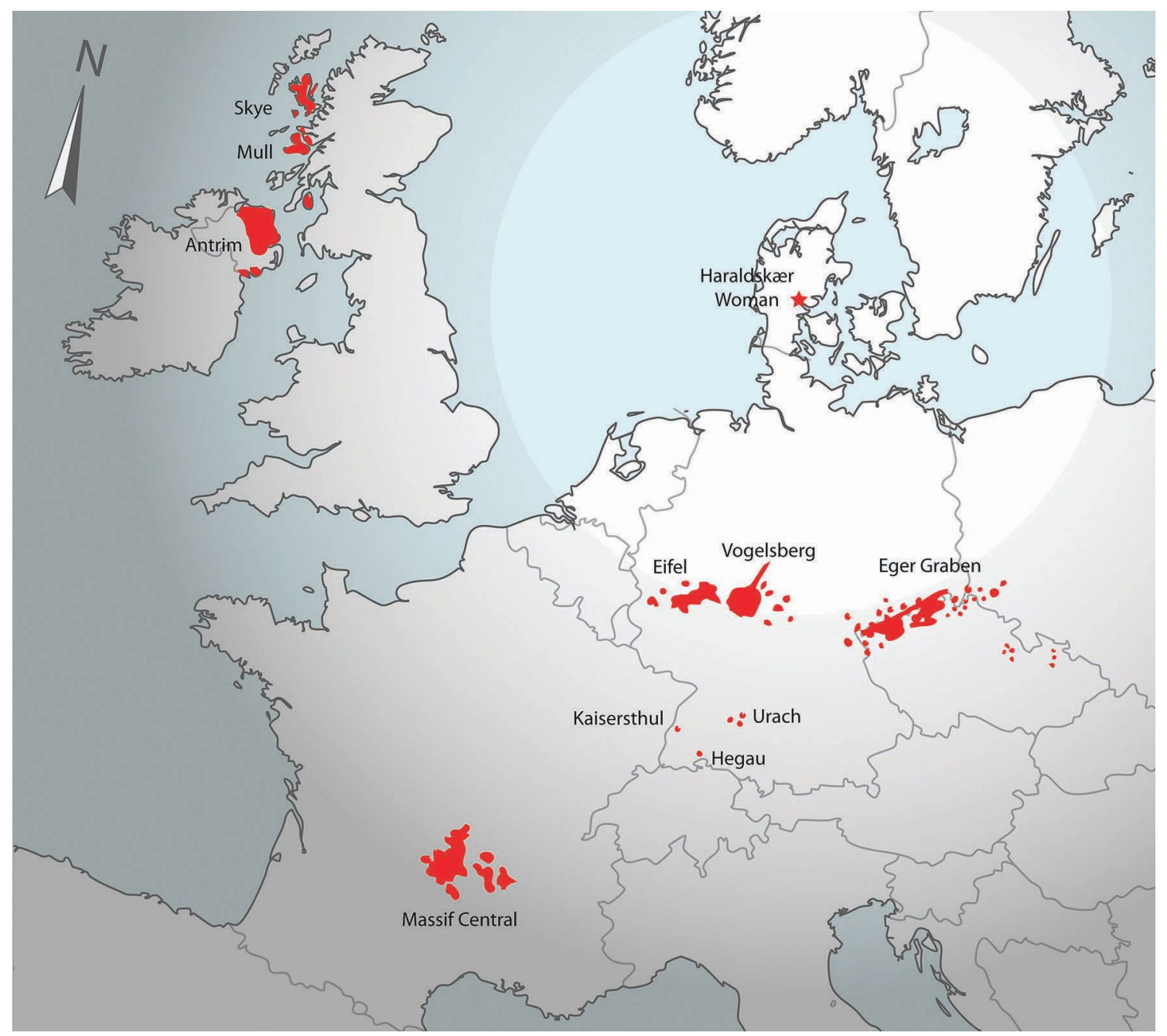

Figure 2 : Karin Margarita Frei et al., Strontium Isotope Investigations of the Haraldskær Woman - A Complex Record of Various Tissues (p. 97) 
Figure 3 : Karin Margarita Frei et al., Strontium Isotope Investigations of the Haraldskær Woman - A Complex Record of Various Tissues (p. 97)
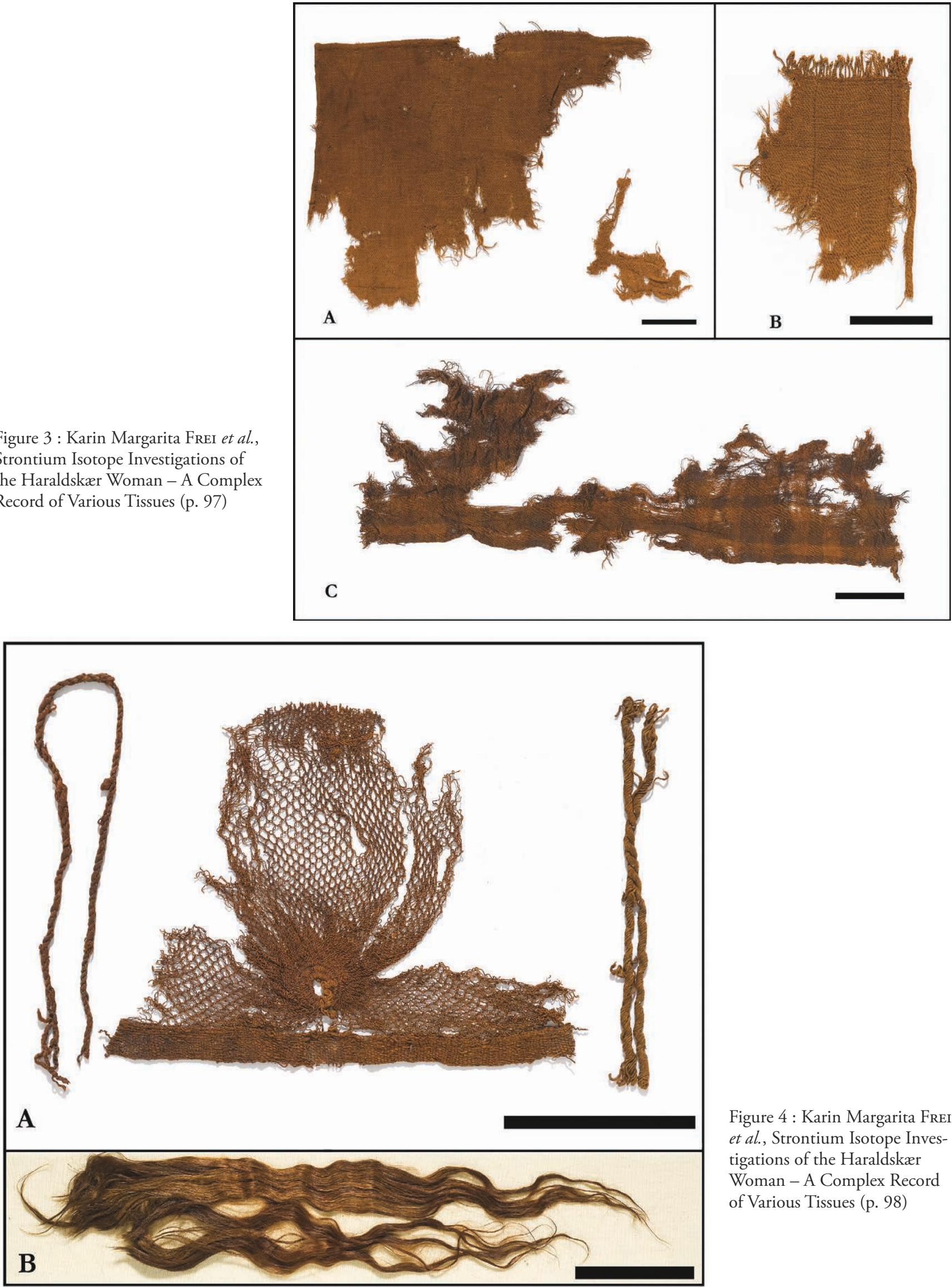

Figure 4 : Karin Margarita FreI et al., Strontium Isotope Investigations of the Haraldskær Woman - A Complex Record of Various Tissues (p. 98) 